\title{
Fall-Prescribed Burn and Spring-Applied Herbicide Effects on Canada Thistle Control and Soil Seedbank in a Northern Mixed-Grass Prairie
}

\author{
Andrea J. Travnicek, ${ }^{1}$ Rodney G. Lym, ${ }^{2}$ and Chad Prosser ${ }^{3}$ \\ Authors are ${ }^{1}$ Environmental Scientist, HPC, Inc., Bismarck, ND 58502; ${ }^{2}$ Professor, Department of Plant Sciences, North Dakota \\ State University, Fargo, ND 58105; and ${ }^{3}$ Ecologist, Theodore Roosevelt National Park, Medora, ND 58645.
}

\begin{abstract}
Prescribed burning in Theodore Roosevelt National Park has played an important role in maintaining a natural ecosystem. However, changes in plant community dynamics caused by burning may have led to an invasion of weedy species such as Canada thistle (Cirsium arvense L.). The objectives of this research were to evaluate the effect of a fall burn before spring herbicide application on Canada thistle control and to evaluate the soil seedbank within Canada thistle infestations. Canada thistle stem densities initially were higher in the burned compared with the nonburned areas because plants were slower to emerge in the nonburned treatments. However, the effect was short-lived, and Canada thistle densities were similar in the burned and nonburned treatments by the second season following the prescribed burn. Canada thistle control averaged $78 \% 60$ days after treatment with clopyralid, clopyralid plus triclopyr, or picloram when spring applied whether or not application was preceded by a prescribed burn. Control declined to less than $60 \%$ by 363 days after application. Grass cover increased from an average of $5 \%$ before treatment to $37 \%$ and $46 \% 60$ and 425 days after herbicide application, respectively, regardless of burn treatment. Forb cover increased following a prescribed burn but was unaffected by herbicide treatment. Overall the number and variety of species in the soil seedbank was not affected by a prescribed burn. A total of 74 species (56 forbs, 13 grasses, and 5 other mesic species) were found in the soil seedbank. However, the majority of the soil seedbank consisted of nondesirable low seral and invasive species including Canada thistle and Kentucky bluegrass (Poa pratensis L.), which accounted for over $80 \%$ of the total germinated seed. Although a prescribed burn caused an initial increase in Canada thistle density and cover, the greater long-term concern may be the lack of desirable species present in the seedbank to replace Canada thistle once the weed is controlled.
\end{abstract}

\section{Resumen}

La quema prescrita en el Parque Nacional Theodore Roosevelt ha jugado un papel importante en mantener un ecosistema natural. Sin embargo, cambios en las dinámicas de la comunidad vegetal causadas por las quemas puede conducir a una invasión de malezas, tal como el "Canada thistle" (Cirsium arvense L.). Los objetivos de esta investigación fueron evaluar el efecto de la quema en otoño antes de la aplicación de herbicidas en primavera para del "Canada thistle" y evaluar el banco de semillas del suelo en infestaciones del "Canada thistle." Las densidades de tallos del "Canada thistle" inicialmente fueron mayores en las áreas quemadas que en las no quemadas porque las plantas fueron lentas en emerger en los tratamientos no quemados. Sin embargo, el efecto fue corto, y para la segunda estación de crecimiento después de la quema prescrita las densidades de "Canada thistle" fueron similares en los tratamientos quemados y no quemados. El control de "Canada thistle" promedio $78 \% 60$ días después de aplicar el tratamiento de clopiralid, clopiralid mas triclopir o picloram, esto cuando las aplicaciones fueron en primavera, sin importar si la aplicación fue precedida por fuego prescrito. 363 días después de la aplicación el control diminuyó a menos del $60 \%$. La cobertura de gramíneas se incrementó de 5\%, antes del tratamiento, a 37\% y $46 \% 60$ y 425 días después de la aplicación del herbicida respectivamente, independientemente del tratamiento de quema. La cobertura de hierbas se incrementó después del tratamiento de quema prescrita, pero no fue afectado por el tratamiento de herbicidas. En general, el número y variedad de especies en el banco de semillas del suelo no fue afectado por la quema prescrita. Un total de 74 especies (56 hierbas, 13 zacates y otras 5 especies mésicas ) fueron encontradas en el banco de semillas del suelo. Pero, la mayoría del banco de semillas del suelo consistió de especies no deseables de etapa seral baja y especies invasoras, incluyendo "Canada thistle" y "Kentucky bluegrass" (Poa pratensis L.), las cuales aportaron más del $80 \%$ del total de las semillas germinadas. Aunque un fuego prescrito causó un incremento inicial de la densidad y cobertura de "Canada thistle", la preocupación a largo plazo puede ser la falta de especies deseables presentes en el banco de semillas para remplazar el "Canada thistle" una vez que la maleza ha sido controlada.

Key Words: invasive species, picloram, clopyralid, revegetation, IPM

Research was funded in part by the National Park Service—Fire Management Center. At the time of the research, Travnicek was a graduate research assistant, Dept of Plant Sciences, North Dakota State University, Fargo, ND 58105.

Correspondence: Rodney G. Lym, Dept of Plant Sciences, North Dakota State University, Fargo, ND 58105-5051. Email: rod.lym@ndsu.edu

Manuscript received 6 July 2004; manuscript accepted 28 January 2005.

\section{INTRODUCTION}

Canada thistle (Cirsium arvense L.) is an herbaceous perennial invasive weed that may be native to southeastern Europe and the eastern Mediterranean (Moore 1975) but is now thought to be naturalized nearly worldwide (Hansen 2001). Canada thistle 
seed was introduced into the United States and Canada in the late 17th century with imported hay, straw, and/or crop seed (Moore 1975). In the United States, Canada thistle is now considered a noxious weed in at least 39 states (Hansen 2001) and is estimated to infest approximately 5 million ha (Duncan et al. 2004), of which 3.3 million ha are rangeland (Hansen 2001).

Canada thistle is a persistent weed that may resist any single management practice (Evans 1984). Several control methods including cultural, chemical, and biological control have been used to manage Canada thistle, but no single treatment method will control this weed. Various combinations of control practices, which include grassland management, mowing, fire, herbicides, and/or biological control agents together, may reduce Canada thistle infestations in the many environments in which it is found.

Alterations in plant community structure and function caused by prescribed fire is variable and may help control weeds, lead to an invasion of exotic species, or allow existing invaders to reach dominant status (Jacobs and Sheley 2003). For instance, 3 consecutive years of summer prescribed burns reduced yellow starthistle (Centaurea solstitialis L.) populations and increased cover of native species, total plant cover, and species richness (DiTomaso et al. 1999). However, yellow starthistle recovered after burn cessation and native species, total plant cover, and species diversity declined (Kyser and DiTomaso 2002). In contrast, a spring prescribed burn increased Dalmatian toadflax (Linaria dalmatica [L.] Miller) biomass and seed production (Jacobs and Sheley 2003), and a single low-intensity fire increased the density and cover of spotted knapweed (Centaurea stoebe spp. micranthos Lam.) and diffuse knapweed (C. diffusa Lam.) (Sheley and Roche 1982).

Canada thistle response to fire has been variable and affected by the season, frequency, and severity of the burn and by the initial plant community composition (Zouhar 2001). Regularly burned areas in Colorado were more resistant to invasion of Canada thistle than areas that were infrequently burned (Reever Morgan et al. 2000). However, Canada thistle can survive fire and sprout vegetatively from the extensive root system or colonize bare ground through seedling establishment (Rowe 1983). In a native mixed-grass prairie in North Dakota, burning in mid-June increased Canada thistle seed production and seedling numbers in the fall, whereas burns conducted from mid-July to mid-August resulted in seedlings killed by frost before establishment (Smith 1985). Regardless of the time of the burn, Canada thistle stem density decreased in the years after the burn.

Seedbank ecology evaluations are crucial for understanding successional patterns following initial control of noxious weeds (Perez et al. 1998). Seeds recovered from a particular seedbank provide a population "memory" of the selective conditions that prevailed in the past as well as current conditions (Templeton and Levin 1979). Once Canada thistle is controlled, the amount of Canada thistle seed in comparison to native species found in a particular seedbank will influence future site recovery.

Prescribed burning has been used with the objective of enhancing the native plant community in Theodore Roosevelt National Park (TRNP) (NPS 1997). Native plant communities need fire to remove litter, cycle nutrients, scarify seeds, and alter competition to remain dominant (Kruger 1983). However, changes in plant community dynamics caused by burning have seemingly lead to an invasion of weedy species, including
Canada thistle in TRNP. The objectives of this research were to evaluate the effect of a prescribed burn alone and in combination with herbicides for Canada thistle control and to estimate plant community response once the weed was removed.

\section{MATERIALS AND METHODS}

\section{Burn-Herbicide Study}

Canada thistle control with herbicides following a prescribed burn was evaluated at the South (lat $46^{\circ} 54^{\prime} \mathrm{N}$, long $103^{\circ} 20^{\prime} \mathrm{W}$, elevation $838 \mathrm{~m}$ ) and North (lat $47^{\circ} 36^{\prime} \mathrm{N}$, long $103^{\circ} 26^{\prime} \mathrm{W}$, elevation $683 \mathrm{~m}$ ) Units of TRNP near Medora, ND. The native vegetation of the study sites consisted mainly of mid- and shortgrass species. Species commonly found in the North and South study areas were blue grama (Bouteloua gracilis [H.B.K.] Lag. ex Griffiths], green needlegrass (Stipa viridula L.), needle and thread (Stipa comata Trin. \& Rupr.), prairie sandreed (Calamovilfa longifolia [Hook.] Scribn.), and western wheatgrass (Agropyron smithii Rydb.). Other species were Kentucky bluegrass (Poa pratensis L.), and western snowberry (Symphoricarpos occidentalis Hook.). Leafy spurge (Euphorbia esula L.) also was present in the South Unit.

The soil at the South Unit was a Flasher-Vebar-Parshall medium loam (mixed, frigid, shallow Typic Ustipsamments; coarse-loamy, mixed, superactive, frigid Typic Haplustolls; coarse-loamy, mixed, superactive, frigid Pachic Haplustolls). The soil at the North Unit was a silty loam (loamy, mixed, superactive, calcareous, frigid, shallow Typic Ustorthents; fineloamy, mixed, superactive, frigid Typic Calciustolls; fine-silty, mixed, superactive, frigid Typic Calciustolls). The organic matter was $9.3 \%$ and $10.6 \%$ at the South and North Units, respectively.

The experiment was designed as a randomized, complete block with treatments in a split-block arrangement. The wholeplot treatment was burned versus nonburned whereas the subplots were herbicide treatments. Both burn and herbicide treatments were randomized in each of three replicates at both locations. Plots were $4.6 \times 5.3 \mathrm{~m}$ with a $1.5-\mathrm{m}$ mowed line separating the split block.

A prescribed burn was conducted on 17 October 2001 and 18 October 2001 at the South and North Units, respectively, of TRNP by the US National Park Service (NPS). The dates were in conjunction with a large landscape prescribed burn at the North Unit. For research purposes, the NPS allowed a burn at the South Unit location only in the study area.

Herbicide treatments were applied to Canada thistle in the rosette to early-bolt growth stage on 12 June 2002 and 13 June 2002 at the South and North Units, respectively. The herbicide treatments included clopyralid (3,6-dichloro-2-pyridinecarboxylic acid) at $340 \mathrm{~g}$ acid equivalent $(\mathrm{ae}) \cdot \mathrm{ha}^{-1}$ plus triclopyr ([\{3,5,6-trichloro-2-pyridinyl $\}$ oxy $]$ acetic acid $)$ at $920 \mathrm{~g}$ $\mathrm{ae} \cdot \mathrm{ha}^{-1}$, clopyralid at $340 \mathrm{~g}$ ae $\cdot \mathrm{ha}^{-1}$, picloram (4-amino3,5,6-trichloro-2-pyridinecarboxylic acid) at $280 \mathrm{~g}$ ae $\cdot \mathrm{ha}^{-1}$, and an untreated control. Herbicides were applied using a tractor-mounted sprayer pressurized by $\mathrm{CO}_{2}$. The sprayer was equipped with a 4-nozzle boom with 8002 flat fan nozzles (TeeJet Spraying Systems Co, Wheaton, IL) delivering 160 $\mathrm{L} \cdot \mathrm{ha}^{-1}$. Herbicides were applied with a nonionic surfactant (NIS, X-77, UAP Industries, Greeley, CO) at $0.25 \%$ v/v. 
Canada thistle control was estimated by change in stem density before and after treatment as determined by stand counts. Counts were conducted immediately before herbicide application in the spring and repeated at 60, 363, and 428 days after treatment (DAT) using a $0.25-\mathrm{m}^{2}$ quadrat. Each plot was subdivided into two $2.3 \times 5.3-\mathrm{m}$ subsections, then three stem counts were made centrally at $0.75-\mathrm{m}$ intervals per subsection for a total of six counts. Cover was evaluated immediately before burning and 275 and 635 days after burn (DAB). A Daubenmire frame $(20 \times 50 \mathrm{~cm})$ was used to determine the percent cover of Canada thistle, grass, forbs, bare ground, shrubs, leafy spurge, and litter (Daubenmire 1959). The frame was placed five times at $0.75-\mathrm{m}$ intervals alternating between the left and right side of the central axis.

\section{Seedbank Study}

The soil seedbank was analyzed at both locations in TRNP and estimated by extracting seed from soil cores taken before herbicide application. A standard golf-cup cutter $(10 \mathrm{~cm}$ in diameter; Par Aide Products Co, Hugo, MN) was used to collect soil samples to a depth of $5 \mathrm{~cm}$. Three soil cores were extracted centrally at $1.5-\mathrm{m}$ intervals down the central axis of each subplot (divided as previously described) for a total of six soil cores per plot sample (8 plots per replication). Samples from each subsection were combined and stored at $3^{\circ} \mathrm{C}$ before analysis.

Seedbank analysis followed the method described by Ter Heerdt et al. (1996). Soil from the cores was washed through coarse $(4 \mathrm{~mm})$ and fine $(210 \mu \mathrm{m})$ sieves to remove roots, pebbles, sand, and clay. The resulting slurry was spread 3- to 5 -mm-thick over a 25 -mm mixed layer of steam-sterilized, greenhouse potting soil and commercial potting mix (Sunshine Mix No. 1, a patented formulation with wetting agents, Fisions Western Corp, Downers Grove, IL) topped with a 13-mm-thick layer of sterile silica sand in $28 \times 56-\mathrm{cm}$ trays. The trays were watered daily, and the greenhouse temperature was maintained between $20^{\circ}$ and $28^{\circ} \mathrm{C}$. Natural and supplemental light at 450 $\mu \mathrm{mol} \cdot \mathrm{m}^{-2} \cdot \mathrm{s}^{-1}$ provided a 16 -hour photoperiod.

Seedlings were identified, counted, and removed from the tray. Plants that could not be identified as seedlings were transplanted to larger pots, fertilized as needed, and grown until identification could be made. Species that required a cold period were vernalized at $4^{\circ} \mathrm{C}$ for 6 weeks and returned to the greenhouse to bolt or flower. Evaluations ended after 6 months. Scientific names of plants generally follow those of the Great Plains Flora Association (1986), except those since revised and commonly accepted. Coefficients of conservation were assigned to plant species based on an assessment provided by The Northern Great Plains Floristic Quality Assessment Panel (2001). Species with coefficients of conservatism of 0 to 3 were classified as low seral, 4 to 10 were classified as high seral, and introduced species were not classified.

\section{Statistical Analysis}

Data from the burn study were analyzed as a randomized complete block design with a split-block arrangement using an analysis of variance (ANOVA). A Bartlett's chi-square test $(P \leq 0.001)$ was performed to determine homogeneity of error mean squares from each evaluation date. Data were homogeneous so a combined ANOVA was conducted. Environments
Table 1. Effect of a fall prescribed burn on Canada thistle density combined across the North and South Unit locations in Theodore Roosevelt National Park. The burn was conducted on 17 October 2001 and 18 October 2001 in the South and North Units, respectively. Averaged over burned and nonburned treatments excluding those that included a herbicide.

\begin{tabular}{lccccc}
\hline & \multicolumn{5}{c}{ Evaluation date/(stems.m ${ }^{-2}$ ) } \\
\cline { 2 - 6 } Treatment & May 2002 & June 2002 & August 2002 & June 2003 & August 2003 \\
\hline Burn & 57 & 58 & 52 & 34 & 39 \\
Nonburn & 12 & 35 & 41 & 28 & 34 \\
LSD (0.05) & 7 & 5 & 9 & NS $^{1}$ & NS \\
\hline
\end{tabular}

${ }^{1} \mathrm{NS}$ indicates nonsignificant; LSD, least significant difference.

(years and sites) were considered random effects, and treatments were fixed. Treatment means were separated using a Fischer's Protected LSD test $(P<0.05)$ and linear contrasts. LSDs followed the method described by Carmer et al. (1989).

Soil seedbank analysis was evaluated using the ANOVA procedure for a randomized complete block design. Soil samples were combined within subsections-three from the left side and three from the right side-and analyzed as two subsamples per plot. Means were separated using Fisher's Protected LSD and considered significant at $P<0.05$.

\section{RESULTS AND DISCUSSION}

\section{Burn Study}

Canada thistle density was higher the spring following a fall prescribed burn compared with the nonburned treatment in TRNP, but stem densities in the burned and nonburned treatments were similar by the second season following the fire (Table 1). In May 2002 (223 DAB), Canada thistle density averaged 57 stems $\cdot \mathrm{m}^{-2}$ in the burned treatment compared with only 12 stems $\cdot \mathrm{m}^{-2}$ in the nonburned treatment. Canada thistle density in the burned treatment, then, gradually declined over the 2-year period of the study to 39 stems $\cdot \mathrm{m}^{-2}$, similar to the stem density in the unburned treatment.

The initial increased density of Canada thistle in the burned compared with the nonburned treatments generally was attributed to the slower emergence of Canada thistle in the nonburned areas (Table 1). As the first season after the burn progressed, Canada thistle density in the nonburned plots gradually increased, whereas the density in the burned plots declined. Similar rapid but unsustained increases in Canada thistle density following a burn have been observed. In Oregon, Canada thistle shoot densities doubled in burned compared with nonburned treatments (Young 1986), whereas in infrequently burned areas in Colorado, Canada thistle density increased rapidly following a spring prescribed burn (Reever Morghan et al. 2000) but then declined as grass production increased.

Litter accumulation in a tallgrass prairie, where fire is infrequent, lowers soil temperatures and reduces the amount of light near the soil surface (Hulbert 1988; Schimel et al. 1991). Soil temperatures can be $4^{\circ}$ to $5^{\circ} \mathrm{C}$ higher on burned areas compared with nonburned areas (Sharrow and Wright 1977). In this study, the prescribed burn reduced the amount of plant cover, which likely increased soil temperature and light on 
Table 2. Effect of a prescribed burn and spring-applied herbicide treatments on Canada thistle density 60 to 428 days after treatment (DAT) with herbicides, combined over burned and nonburned treatments and South and North Units of Theodore Roosevelt National Park.

\begin{tabular}{lcccc}
\hline & & 60 DAT & 363 DAT & 428 DAT \\
\cline { 4 - 5 } \multicolumn{1}{c}{ Herbicide $^{1}$} & Rate $\left(\mathrm{g} \mathrm{ae} \cdot \mathrm{ha}^{-1}\right)^{2}$ & \multicolumn{3}{c}{$\left(\mathrm{stems} \cdot \mathrm{m}^{-2}\right)$} \\
\hline Clopyralid + triclopyr & $340+920$ & 12 & 15 & 23 \\
Clopyralid & 340 & 8 & 11 & 17 \\
Picloram & 280 & 12 & 17 & 25 \\
Untreated & - & 47 & 31 & 37 \\
LSD $(0.05)$ & - & 13 & 13 & NS
\end{tabular}

${ }^{1} \mathrm{NIS}, \mathrm{X}-77$ nonionic surfactant applied at $0.25 \%$ with all treatments; UAP Industries, $7251 \mathrm{~W}$ 4th Street, Greeley, CO 80634

${ }^{2}$ LSD indicates least significant difference; NS, nonsignificant; ae, acid equivalent.

the soil surface. These conditions initially favored earlier Canada thistle emergence, which is consistent with observations that weedy species with early emergence and rapid growth characteristics initially become dominant following fire (Sheley et al. 1998). Canada thistle density then declined as other species regrew and competed for nutrients and light.

The effect of herbicides on Canada thistle stem density was similar whether or not application was preceded by a prescribed burn (data were homogenous) at both locations; therefore, data were combined over location and burn treatment (Table 2). Initially, all herbicide treatments reduced Canada thistle density, but Canada thistle regrew rapidly, and density was similar to the control by 428 DAT. Canada thistle density was reduced from 47 stems $\cdot \mathrm{m}^{-2}$ to 8 stems $\cdot \mathrm{m}^{-2}$ (83\% control) 60 DAT when clopyralid was applied alone and to $12 \mathrm{stems} \cdot \mathrm{m}^{-2}(74 \%$ control) when clopyralid plus triclopyr or picloram alone were applied. However, Canada thistle stem density increased thereafter and averaged 14 and 22 stems $\cdot \mathrm{m}^{-2} 363$ and 428 DAT, respectively, regardless of herbicide treatment.

These comparative observations of rapid but relatively shortterm Canada thistle control are consistent with other studies involving clopyralid plus triclopyr, clopyralid, and picloram applied in June (Lym 2003). In North Dakota, Canada thistle control 90 DAT averaged $91 \%$ with clopyralid plus triclopyr applied at the same rate as in this study, but control at 364 and 455 DAT had declined to $70 \%$ and $39 \%$, respectively. Herbicide treatments applied in the fall generally provided better longterm Canada thistle control than spring treatments (Miller and Lym 1998) but also allowed the plants to set seed in the interim.

Canada thistle stem density declined from 47 stems $\cdot \mathrm{m}^{-2} 60$ DAT to 31 and 37 stems $\cdot \mathrm{m}^{-2} 363$ and 428 DAT, respectively, in the untreated plots (Table 2). The decline may have been the result of normal population variation and/or below normal precipitation received during the course of this study. In the South Unit, there was 24 and $21 \mathrm{~cm}$ of precipitation in 2002 and 2003, respectively, compared with the 30-year average of $38 \mathrm{~cm}$. In the North Unit, precipitation for each year was normal but was below average early in the growing season in both 2002 and 2003. Drought may have reduced Canada thistle root tissue as observed following a dry winter in Nebraska (Lauridson et al. 1983) or killed portions of the root system (Donald 1993) resulting in the decreased number of stems observed in this study.
Foliar cover of Canada thistle was not affected by burning alone and averaged $20 \%$ (21\% burn vs. $18 \%$ nonburn) the growing season following the burn treatment (Table 3). However, Canada thistle cover was reduced by herbicide application. Clopyralid plus triclopyr, clopyralid, and picloram similarly reduced Canada thistle foliar cover from $64 \%$ in the untreated areas to an average of $5 \%$ in the herbicide-treated areas. The reduction in Canada thistle cover was short-lived, and cover was similar to the untreated control (36\%) two growing seasons after the prescribed burn (data not presented).

Grass foliar cover was unaffected by the burn treatment, but cover increased following herbicide application and averaged $37 \%$ compared with $5 \%$ in the control (Table 3). Grass populations may have increased in response to the decrease in Canada thistle density and cover (Beck and Sebastian 2000). In this study, herbicides reduced the cover of Canada thistle in the area, and grasses were able to recover.

Once established, perennial grasses may be able to suppress and compete successfully with Canada thistle (Wilson and Kachman 1999). During this study, grass cover remained high in all herbicide-treated areas and averaged $46 \%$ compared with $13 \%$ in the untreated control two growing seasons after the fall prescribed burn (data not presented). Grass cover was similar regardless of whether the area had been burned, and it was the only cover component evaluated that differed from the untreated control two growing seasons after treatment.

Forb cover in the growing season following the fall prescribed burn increased to $4 \%$ in the burned area compared with a $1 \%$ increase in nonburned treatments in TRNP (Table 3). Herbicides alone did not affect forb cover. Similarly, a grassland community infested with yellow starthistle shifted back toward conditions that favored growth of native forbs following a prescribed burn (Kyser and DiTomaso 2002). In this study, once Canada thistle was controlled by herbicides in the burned areas, native forbs successfully reestablished.

The amount of bare ground tended to increase the season following the prescribed burn compared with nonburned treatments, and more bare ground was found when herbicides were applied than compared with the control (Table 3). Bare ground averaged $41 \%$ and $43 \%$ following clopyralid plus triclopyr and picloram treatments, respectively, compared with $2 \%$ in the control and $18 \%$ with clopyralid alone. Following a prescribed burn, increased bare ground is available for new species establishment (Pollack and Kan 1998). However, in this study, bare ground was not observed in the nonburned treatment, so the effect of herbicide treatments could only be made in the burned areas.

Picloram and clopyralid plus triclopyr control a wide spectrum of broadleaf species (Donald 1990; Lee et al. 2001) and may have reduced other species besides Canada thistle. Clopyralid has a narrow weed control spectrum (Carrithers et al. 2001) that is more specific to certain plants such as Canada thistle, which may account for the lower amount of bare ground observed in this treatment.

Shrub cover was similar across treatments for both growing seasons following the fall prescribed burn, whereas litter tended to be reduced from $16 \%$ to $3 \%$ following the burn treatment (Table 3). Prescribed burn and herbicide treatments evaluated in this study did not affect leafy spurge foliar cover in the South Unit. 
Table 3. Effect of herbicide treatments on percentage of cover by Canada thistle, grass, forbs, bare ground, shrubs, leafy spurge, and litter 1 growing season after a fall prescribed burn in the North and South Units of Theodore Roosevelt National Park.

\begin{tabular}{|c|c|c|c|c|c|c|c|c|}
\hline \multirow[b]{2}{*}{ Treatment $^{1}$} & \multirow[b]{2}{*}{ Rate $\left(\mathrm{g}\right.$ ae $\left.\cdot \mathrm{ha}^{-1}\right)$} & \multicolumn{7}{|c|}{ (\% foliar cover) } \\
\hline & & $\begin{array}{l}\text { Canada } \\
\text { thistle }\end{array}$ & Grass & Forbs & Bare & Shrubs & $\begin{array}{c}\text { Leafy } \\
\text { spurge }^{2}\end{array}$ & Litter \\
\hline Prior to treatment ${ }^{3}$ & & 71 & 12 & 0 & 1 & 15 & 1 & - \\
\hline \multicolumn{9}{|l|}{ Main effect } \\
\hline \multicolumn{9}{|l|}{ Burns (avg. across herbicide) } \\
\hline Burn & & 21 & 22 & 4 & 26 & 20 & 9 & 3 \\
\hline Nonburn & & 18 & 35 & 1 & 0 & 30 & 2 & 16 \\
\hline LSD (0.05) burn & & $\mathrm{NS}^{6}$ & NS & 0.5 & NS & NS & NS & NS \\
\hline \multicolumn{9}{|l|}{ Interaction Burn X herbicide } \\
\hline \multicolumn{9}{|l|}{ Burn } \\
\hline Clopyralid + triclopyr $^{4}$ & $340+920$ & 9 & 33 & 3 & 41 & 13 & 2 & 0 \\
\hline Clopyralid $^{4}$ & 340 & 1 & 30 & 4 & 18 & 33 & 14 & 8 \\
\hline Picloram ${ }^{4}$ & 280 & 5 & 21 & 2 & 43 & 22 & 10 & 2 \\
\hline Untreated & - & 69 & 4 & 6 & 2 & 13 & 11 & 0 \\
\hline \multicolumn{9}{|l|}{ Nonburn } \\
\hline Clopyralid + triclopyr $^{4}$ & $340+920$ & 5 & 54 & 0 & 0 & 14 & 1 & 27 \\
\hline Clopyralid $^{4}$ & 340 & 3 & 38 & 2 & 0 & 45 & 0 & 11 \\
\hline Picloram ${ }^{4}$ & 280 & 6 & 42 & 0 & 0 & 28 & 3 & 23 \\
\hline Untreated & - & 58 & 6 & 2 & 0 & 32 & 5 & 1 \\
\hline LSD (0.05) burn $\times$ herb. & & NS & NS & NS & 23 & NS & NS & NS \\
\hline \multicolumn{9}{|l|}{ Herbicides (avg. across burn) } \\
\hline Clopyralid + triclopyr $^{4}$ & $340+920$ & 7 & 44 & 2 & $x^{5}$ & 14 & 2 & 14 \\
\hline Clopyralid $^{4}$ & 340 & 2 & 34 & 3 & $x$ & 39 & 7 & 10 \\
\hline Picloram ${ }^{4}$ & 280 & 6 & 32 & 1 & $x$ & 25 & 7 & 13 \\
\hline Untreated & - & 64 & 5 & 4 & $x$ & 23 & 8 & 1 \\
\hline LSD (0.05) herbicide & & 16 & 11 & NS & & NS & NS & NS \\
\hline
\end{tabular}

${ }^{1}$ Burn conducted on 17 October 2001 and 18 October 2001 and herbicides applied on 12 June 2002 and 13 June 2002 ; cover was evaluated on 14 August 2002.

${ }^{2}$ Leafy spurge was only present at the South Unit.

${ }^{3}$ Data not included in statistical analysis.

${ }^{4} \mathrm{NIS}, \mathrm{X}-77^{\circledR}$ nonionic surfactant applied at $0.25 \%$; UAP Industries, $7251 \mathrm{~W}$ 4th Street, Greeley, C0 80634.

${ }^{5}$ Data for percentage of bare ground in the nonburn treatment were not normally distributed and could not be averaged.

${ }^{6}$ LSD indicates least significant difference; NS, nonsignificant; ae, acid equivalent.

\section{Seedbank Study}

The majority of seed in the soil seedbank in the South and North Units of TRNP consisted of low seral species (Table 4). A total of 74 species germinated across all soil cores taken in both the South and North Units of TRNP. Of these, 56 forbs, 13 grasses, and 5 other mesic species were identified. For each Unit, species were subjectively placed into 6 categories: high seral grasses, low seral grasses, high seral forbs, low seral forbs, other mesic species, and introduced species, which included Canada thistle and Kentucky bluegrass. Species categorized with a coefficient of conservatism of 3 and under, establish and compete more effectively than those categorized as 4 and over and often take space from those 4 and over (Kirby et al. 2003).

In the South Unit, seedling density from 5 -cm soil depth was 7138 seedlings per $\mathrm{m}^{2}$ (Table 4). A total of 53 species germinated from the soil cores; 40 forbs, 10 grasses, and 3 other mesic species. Perennials comprised $74 \%$ of the species; $22 \%$ were annuals and $4 \%$ biennials. Of these, 38 species were native with 16 considered high seral and 22 considered low seral. Fifteen species were introduced.

Total high seral species, grasses and forbs inclusive, accounted for only $7 \%$ of the species identified (Table 4$)$. High seral species are found in natural, less-disturbed areas and have a coefficient of conservatism value of 4 to 10 (The Northern Great Plains Floristic Quality Assessment Panel 2001). Of the 5 high seral grasses that germinated, prairie wedgegrass (Sphenopholis obtusata [Michx.] Scribn.) and fowl bluegrass (Poa palustris L.) comprised $88 \%$ of the high seral grasses present.

Total low seral species, grasses and forbs inclusive, constituted $37 \%$ of total germinating seedlings in the South Unit (Table 4). Low seral species with a coefficient of conservatism value between 0 and 3 are indicative of disturbance. Foxtail barley (Hordeum jubatum L.) was the only low seral grass that germinated in the South Unit seedbank, but 17 low seral forbs were identified. Stinging nettle (Urtica dioica L.) comprised $63 \%$ of the low seral forbs, and when combined with 
Table 4. Plant species germinated from soil cores extracted from the South and North Units of Theodore Roosevelt National Park, including life form, origin, coefficient of conservatism, number of seedlings germinating, and percentage of total seedlings emerged.

\begin{tabular}{|c|c|c|c|c|c|c|c|c|}
\hline \multirow[b]{2}{*}{ Scientific name ${ }^{1}$} & \multirow[b]{2}{*}{ Common name } & \multirow[b]{2}{*}{ Life $^{2}$} & \multirow[b]{2}{*}{ Origin $^{3}$} & \multirow[b]{2}{*}{ C-value ${ }^{4}$} & \multicolumn{2}{|c|}{ South } & \multicolumn{2}{|c|}{ North } \\
\hline & & & & & $\left(\mathrm{No}^{5}{ }^{5}\right)$ & $\left(\%^{6}\right)$ & $\left(\right.$ №. $\left.{ }^{5}\right)$ & $\left(\%^{6}\right)$ \\
\hline \multicolumn{9}{|l|}{ High Seral Grasses } \\
\hline Muhlenbergia racemosa (Michx.) B.S.P. & Marsh muhly & $\mathrm{P}$ & $\mathrm{N}$ & 4 & 10 & 0.14 & 16 & 0.51 \\
\hline Poa interior Rydb. & Inland bluegrass & $\mathrm{P}$ & $\mathrm{N}$ & 5 & - & - & 1 & 0.03 \\
\hline Poa palustris $\mathrm{L}$. & Fowl bluegrass & $\mathrm{P}$ & $\mathrm{N}$ & 4 & 50 & 0.70 & 206 & 6.57 \\
\hline Puccinellia nuttalliana (Schult.) A. Hitchc. & Alkali grass & $\mathrm{P}$ & $\mathrm{N}$ & 4 & - & - & 3 & 0.10 \\
\hline Sphenopholis obtusata (Michx.) Scribn. & Prairie wedgegrass & A/P & $\mathrm{N}$ & 7 & 41 & 0.57 & 17 & 0.54 \\
\hline Sporobolus cryptandrus (Torr.) A. Gray & Sand dropseed & $\mathrm{P}$ & $\mathrm{N}$ & 6 & 1 & 0.01 & 6 & 0.19 \\
\hline Stipa viridula Trin. & Green needlegrass & $\mathrm{P}$ & $\mathrm{N}$ & 5 & 2 & 0.03 & 5 & 0.16 \\
\hline Subtotal & & & & & 104 & 1.45 & 254 & 8.10 \\
\hline \multicolumn{9}{|l|}{ Low Seral Grasses } \\
\hline Elymus canadensis $\mathrm{L}$. & Canada wildrye & $\mathrm{P}$ & $\mathrm{N}$ & 3 & - & - & 9 & 0.29 \\
\hline Hordeum jubatum L. & Foxtail barley & $\mathrm{P}$ & $\mathrm{N}$ & 0 & 1 & 0.01 & - & - \\
\hline Subtotal & & & & & 1 & 0.01 & 9 & 0.29 \\
\hline \multicolumn{9}{|l|}{ High Seral Forbs } \\
\hline Androsace occidentalis Pursh. & Western rock jasmine & A & $\mathrm{N}$ & 5 & 4 & 0.06 & 140 & 4.47 \\
\hline Arabis drummondii Gray & Drummond's rockcress & $\mathrm{B} / \mathrm{P}$ & N & 8 & - & - & 3 & 0.10 \\
\hline Arabis hirsuta (L.) Scop. & Hairy rockcress & $\mathrm{B} / \mathrm{P}$ & $\mathrm{N}$ & 7 & 2 & 0.03 & 12 & 0.38 \\
\hline Artemisia frigida Willd. & Fringed sage & $P$ & $\mathrm{~N}$ & 4 & - & - & 4 & 0.13 \\
\hline Campanula rotundifolia L. & Harebell & $\mathrm{P}$ & $\mathrm{N}$ & 7 & - & - & 4 & 0.13 \\
\hline Collomia linearis Nutt. & Collomia & A & $\mathrm{N}$ & 5 & - & - & 1 & 0.03 \\
\hline Epilobium leptophyllum Raf. & Narrow-leaved willow-herb & $\mathrm{P}$ & $\mathrm{N}$ & 6 & 4 & 0.06 & 18 & 0.57 \\
\hline Erigeron glabellus Nutt. & Smooth fleabane & $\mathrm{B} / \mathrm{P}$ & $\mathrm{N}$ & 7 & 1 & 0.01 & 15 & 0.48 \\
\hline Galium boreale L. & Northern bedstraw & $P$ & $\mathrm{~N}$ & 4 & - & - & 44 & 1.40 \\
\hline Galium triflorum Michx. & Sweet-scented bedstraw & $\mathrm{P}$ & $\mathrm{N}$ & 7 & 137 & 1.92 & 68 & 2.17 \\
\hline Glaux maritima L. & Sea milkwort & $\mathrm{P}$ & $\mathrm{N}$ & 4 & 8 & 0.11 & 30 & 0.96 \\
\hline Helianthus maximilianii Schrad. & Maximilian sunflower & $\mathrm{P}$ & $\mathrm{N}$ & 5 & 4 & 0.06 & - & - \\
\hline Heuchera richardsonii R. & Alumroot & $\mathrm{P}$ & $\mathrm{N}$ & 8 & - & - & 9 & 0.29 \\
\hline Lycopus americanus Muhl. ex Bart. & American bugleweed & $\mathrm{P}$ & $\mathrm{N}$ & 4 & 4 & 0.06 & - & - \\
\hline Monarda fistulosa L. & Wild bergamot & $\mathrm{P}$ & $\mathrm{N}$ & 5 & 15 & 0.21 & 10 & 0.32 \\
\hline Potentilla arguta Pursh. & Tall cinquefoil & $\mathrm{P}$ & $\mathrm{N}$ & 8 & 1 & 0.01 & - & - \\
\hline Ranunculus rhomboideus Goldie & Prairie buttercup & $\mathrm{P}$ & $\mathrm{N}$ & 8 & - & - & 5 & 0.16 \\
\hline Solidago gigantea Ait. & Late goldenrod & $\mathrm{P}$ & $\mathrm{N}$ & 4 & 241 & 3.38 & 1 & 0.03 \\
\hline Subtotal & & & & & 421 & 5.91 & 364 & 11.62 \\
\hline \multicolumn{9}{|l|}{ Low Seral Forbs } \\
\hline Achillea millefolium $\mathrm{L}$. & Yarrow & $\mathrm{P}$ & $\mathrm{N}$ & 3 & - & - & 1 & 0.03 \\
\hline Amaranthus retroflexus $\mathrm{L}$. & Redroot pigweed & A & $\mathrm{N}$ & 0 & - & - & 1 & 0.03 \\
\hline Artemisia Iudoviciana Nutt. & White sage & $\mathrm{P}$ & $\mathrm{N}$ & 3 & 61 & 0.86 & 44 & 1.40 \\
\hline Aster brachyactis Blake & Rayless aster & A & $\mathrm{N}$ & 0 & 4 & 0.06 & 14 & 0.44 \\
\hline Aster ericoides $\mathrm{L}$. & White heathaster & $\mathrm{P}$ & $\mathrm{N}$ & 2 & 1 & 0.01 & 4 & 0.13 \\
\hline Chenopodium pratericola Rydb. & Desert goosefoot & A & $\mathrm{N}$ & 1 & - & - & 4 & 0.13 \\
\hline Conyza canadensis (L.) Cronq. & Horseweed & A & $\mathrm{N}$ & 0 & 215 & 3.01 & 235 & 7.50 \\
\hline Epilobium ciliatum Raf. & Willow-herb & $\mathrm{P}$ & $\mathrm{N}$ & 3 & 391 & 5.48 & 446 & 14.24 \\
\hline Erysimum asperum (Nutt.)DC. & Western wallflower & $\mathrm{B} / \mathrm{P}$ & $\mathrm{N}$ & 3 & - & - & 4 & 0.13 \\
\hline Euphorbia serpyllifolia Pers. & Thyme-leaved spurge & A & $\mathrm{N}$ & 0 & 9 & 0.13 & 8 & 0.26 \\
\hline Hackelia deflexa (Wahl.) Opiz. & Nodding stickseed & $\mathrm{B} / \mathrm{P}$ & $\mathrm{N}$ & 0 & 23 & 0.32 & 30 & 0.95 \\
\hline Hedeoma hispidum Pursh. & Rough false pennyroyal & A & $\mathrm{N}$ & 2 & - & - & 1 & 0.03 \\
\hline Mentha arvensis $\mathrm{L}$. & Field mint & $\mathrm{P}$ & $\mathrm{N}$ & 3 & 54 & 0.76 & 16 & 0.51 \\
\hline Oenothera biennis $\mathrm{L}$. & Common evening-primrose & B & $\mathrm{N}$ & 0 & 13 & 0.18 & 1 & 0.03 \\
\hline Oxalis stricta $\mathrm{L}$. & Yellow woodsorrel & A/P & $\mathrm{N}$ & 0 & 3 & 0.04 & 32 & 1.02 \\
\hline Parietaria pensy/vanica Muhl. ex Willd. & Pennsylvania pellitory & A & $\mathrm{N}$ & 3 & 4 & 0.06 & 1 & 0.03 \\
\hline
\end{tabular}


Table 4. Continued.

\begin{tabular}{|c|c|c|c|c|c|c|c|c|}
\hline \multirow[b]{2}{*}{ Scientific name $^{1}$} & \multirow[b]{2}{*}{ Common name } & \multirow[b]{2}{*}{ Life $^{2}$} & \multirow[b]{2}{*}{ Origin $^{3}$} & \multirow[b]{2}{*}{ C-value ${ }^{4}$} & \multicolumn{2}{|c|}{ South } & \multicolumn{2}{|c|}{ North } \\
\hline & & & & & $\left(\mathrm{No}^{5}\right)^{5}$ & $\left(\%{ }^{6}\right)$ & $\left(\mathrm{No}^{5}{ }^{5}\right)$ & $\left(\%^{6}\right)$ \\
\hline Potentilla norvegica L. & Norwegian cinquefoil & $A / B / P$ & $\mathrm{~N}$ & 0 & 125 & 1.75 & 27 & 0.86 \\
\hline Ranunculus cymbalaria Pursh & Shore buttercup & $\mathrm{P}$ & N & 3 & 81 & 1.13 & 2 & 0.06 \\
\hline $\begin{array}{l}\text { Ratibida columnifera (Nutt.) } \\
\text { Woot. \& Standl. }\end{array}$ & Prairie coneflower & $P$ & $\mathrm{~N}$ & 3 & - & - & 10 & 0.31 \\
\hline Rumex mexicanus Meisn. & Willow-leaved dock & $P$ & N & 1 & 1 & 0.01 & - & - \\
\hline Solidago canadensis $\mathrm{L}$. & Canada goldenrod & $P$ & N & 1 & 4 & 0.06 & - & - \\
\hline Veronica peregrine L. & Purslane speedwell & $A$ & N & 0 & 3 & 0.04 & - & - \\
\hline Urtica dioica $\mathrm{L}$. & Stinging nettle & $P$ & N & 0 & 1670 & 23.40 & 276 & 8.81 \\
\hline Subtotal & & & & & 2662 & 37.30 & 1157 & 36.92 \\
\hline \multicolumn{9}{|l|}{ Other Mesic } \\
\hline $\begin{array}{l}\text { Carex brevior (Dew.) } \\
\text { Mack. ex Lunell }\end{array}$ & Shortbeak sedge & $P$ & N & 4 & 2 & 0.03 & 4 & 0.13 \\
\hline Carex saximontana Mack. & Rocky mountain sedge & $P$ & N & 10 & - & - & 21 & 0.67 \\
\hline Carex spp. & Sedge & $P$ & N & - & - & - & 95 & 3.03 \\
\hline Juncus balticus Willd. & Baltic rush & $P$ & N & 5 & 46 & 0.64 & - & - \\
\hline Typha spp. & Cattail & $P$ & N & - & 74 & 1.04 & 14 & 0.44 \\
\hline Subtotal & & & & & 122 & 1.71 & 134 & 4.27 \\
\hline \multicolumn{9}{|l|}{ Introduced } \\
\hline Artemisia biennis Willd. & Biennial wormwood & B & 1 & * & 401 & 5.62 & 2 & 0.06 \\
\hline Agropyron cristatum (L.) Gaertn. & Crested wheatgrass & $P$ & 1 & * & 28 & 0.39 & - & - \\
\hline Chenopodium album $\mathrm{L}$. & Lamb's quarters & A & I & * & 8 & 0.11 & 15 & 0.48 \\
\hline Chenopodium glaucum $\mathrm{L}$. & Oak-leaved goosefoot & A & 1 & * & 97 & 1.36 & 3 & 0.10 \\
\hline Cirsium arvense (L.) Scop. & Canada thistle & $P$ & I & * & 1513 & 21.20 & 723 & 23.07 \\
\hline $\begin{array}{l}\text { Descurainia sophia (L.) } \\
\text { Webb. ex Prantl. }\end{array}$ & Flixweed & $A / B$ & 1 & * & 29 & 0.41 & 60 & 1.91 \\
\hline $\begin{array}{l}\text { Elytrigia repens (L.) Desv. } \\
\text { ex Nevski }\end{array}$ & Quackgrass & $P$ & 1 & * & 3 & 0.04 & 19 & 0.60 \\
\hline Erysimum cheiranthoides $\mathrm{L}$. & Wormseed wallflower & $A / B$ & I & * & 206 & 2.89 & 32 & 1.02 \\
\hline Euphorbia esula L. & Leafy spurge & $P$ & I & * & 135 & 1.89 & 2 & 0.06 \\
\hline Lactuca serriola L. & Prickly lettuce & $A$ & 1 & * & 3 & 0.04 & 5 & 0.16 \\
\hline Nepeta cataria L. & Catnip & $P$ & I & * & - & - & 3 & 0.10 \\
\hline Poa compressa L. & Canada bluegrass & $P$ & I & * & 5 & 0.07 & - & - \\
\hline Poa pratensis $\mathrm{L}$. & Kentucky bluegrass & $P$ & 1 & * & 1179 & 16.52 & 310 & 9.89 \\
\hline Polygonum convolvulus L. & Wild buckwheat & $A$ & I & * & 24 & 0.34 & 19 & 0.60 \\
\hline Rumex crispus $\mathrm{L}$. & Curly dock & $P$ & I & * & 144 & 2.02 & 3 & 0.10 \\
\hline Senecio vulgaris $\mathrm{L}$. & Groundsel & $A / B$ & I & * & - & - & 5 & 0.16 \\
\hline Silene cserei Baumg. & Smooth catchfly & $\mathrm{B} / \mathrm{P}$ & I & * & - & - & 4 & 0.13 \\
\hline Sonchus arvensis $\mathrm{L}$. & Perennial sowthistle & $\mathrm{P}$ & $\mathrm{N}$ & * & 31 & 0.43 & 5 & 0.16 \\
\hline Taraxacum officinale Weber & Dandelion & $P$ & I & * & 23 & 0.32 & 6 & 0.19 \\
\hline Subtotal & & & & & 3829 & 53.63 & 1216 & 38.76 \\
\hline Total & & & & & 7139 & 100 & 3134 & 100 \\
\hline Standard error & & & & & 419 & & 107 & \\
\hline
\end{tabular}

${ }^{1}$ Scientific nomenclature follows the Flora of the Great Plains, except for the updated name for quackgrass (Great Plains Flora Association 1986).

${ }^{2}$ Life-form: $P$ indicates perennial; B, biennial; $A$, annual.

${ }^{3}$ Origin: I indicates introduced; $N$, native.

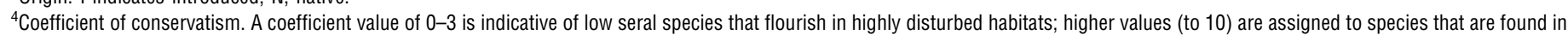
natural, less-disturbed areas; and $\left({ }^{\star}\right)$ is indicative of introduced species (The Northern Great Plains Floristic Quality Assessment Panel 2001).

${ }^{5}$ Total number of seedlings germinating per $\mathrm{m}^{2}$ from samples collected to a depth of $5 \mathrm{~cm}$.

${ }^{6}$ Percentage of total seedlings that germinated across all soil cores. 
Table 5. Effect of a prescribed burn on soil seedbank composition the following growing season, combined across repetition of the experiment in the South and North Units of Theodore Roosevelt National Park.

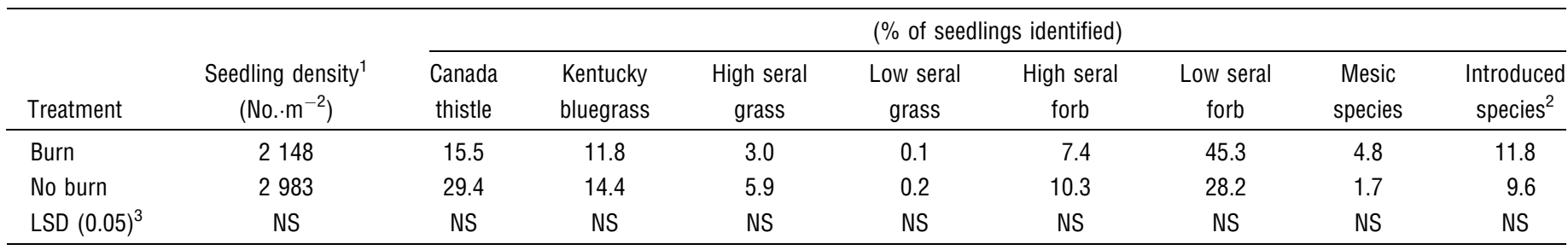

${ }^{1}$ Total average number of seedlings germinating per $1 \mathrm{~m}^{2}$ in soil samples collected to a depth of $5 \mathrm{~cm}$ for each treatment.

${ }^{2}$ Introduced species exclude Canada thistle and Kentucky bluegrass.

${ }^{3}$ LSD indicates least significant difference; NS, nonsignificant.

horseweed (Conyza canadensis [L.] Cronq.), willow-herb (Epilobium ciliatum Raf.), and Norwegian cinquefoil (Potentilla norvegica L.), accounted for over $90 \%$ of the low seral forbs identified (Table 4). These 4 pioneer species are the first to establish after a disturbance and are prolific seed producers that quickly germinate (Larson 1993; Eggers and Reed 1997). Willow-herb is not a species characteristic of the plant community in the South Unit and likely was only able to germinate because of the favorable conditions that existed in the greenhouse.

Introduced species, including Canada thistle and Kentucky bluegrass, comprised $54 \%$ of the total seedlings identified in the South Unit (Table 4). Canada thistle alone comprised $21 \%$ of the total seedlings present, and Kentucky bluegrass represented $16 \%$. Canada thistle and Kentucky bluegrass are both prolific seed producers. Kentucky bluegrass is an introduced species but is considered naturalized. Kentucky bluegrass provides highquality forage in the spring but may not be desirable because it can become dominant and replace other native species (Balasko et al. 1995).

Five introduced forb species, biennial wormwood (Artemisia biennis Willd.), oak-leaved goosefoot (Chenopodium glaucum L.), wormseed wallflower (Erysimum cheiranthoides L.), leafy spurge (Euphorbia esula L.), and curly dock (Rumex crispus L.), accounted for most of the remaining introduced species in the South Unit (Table 4). These species are considered prolific seed producers that quickly establish in an area that has been disturbed.

Canada thistle, Kentucky bluegrass, and introduced species, when combined with the low seral species, forbs, and grasses, accounted for $91 \%$ of all species that germinated in the South Unit (Table 4). Therefore, even if Canada thistle is controlled, a long-term weed management program that includes reseeding of desirable species may need to be considered to revegetate the area to more desirable, native species.

A total of 66 species germinated from the soil cores in the North Unit of TRNP; 53 forbs, 9 grasses, and 4 other species were identified (Table 4). The seedling density in the North Unit to $5 \mathrm{~cm}$ of soil depth was 3134 seedlings per $\mathrm{m}^{2}$, which was only $44 \%$ of the seedling density observed in the South Unit. Perennials constituted $72 \%$ of the species; $23 \%$ were annuals and $5 \%$ biennials. Of these, 47 species were native with 22 considered high seral and 25 considered low seral. Seventeen species were introduced. Even though fewer than half as many seedlings germinated in the North Unit as compared with the South Unit, the North Unit had greater species richness (Table 4).

Total high seral species, grasses and forbs inclusive, comprised $20 \%$ of the total germinated species (Table 4 ). Seven high seral grasses were identified, including $81 \%$ fowl bluegrass and $2 \%$ green needlegrass. Of the 15 high seral forbs that germinated, western rock jasmine (Androsace occidentalis Pursh), northern bedstraw (Galium boreale L.), and sweet-scented bedstraw (G. triflorum Michx.) constituted 69\% of the seedlings.

Total low seral species, grasses and forbs inclusive, accounted for $37 \%$ of the total seedlings identified in the North Unit (Table 4). Canada wildrye (Elymus canadensis L.) was the only low seral grass that germinated in the greenhouse. Similar to the South Unit, stinging nettle, horseweed, and willow-herb combined represented the majority $(83 \%)$ of the low seral forbs.

Introduced species, including Canada thistle and Kentucky bluegrass, comprised $39 \%$ of the total germinated species (Table 4). Of the introduced species, Canada thistle comprised $23 \%$ of the total seedlings present, Kentucky bluegrass was $10 \%$, and other introduced species combined accounted for $6 \%$ of the total species identified. Three introduced forb species, wild buckwheat (Polygonum convolvulus L.), flixweed (Descurainia sophia [L.] Webb ex Prantl.), and wormseed wallflower, comprised 3\% of the introduced species. These 3 forbs are also pioneer species and prolific seed producers (Great Plains Flora Association 1986). Quackgrass, the only introduced grass species, made up $10 \%$ of the introduced seedlings identified.

Canada thistle, Kentucky bluegrass, and other introduced species combined with the low seral grass and forb species accounted for $76 \%$ of the total seedlings in the North Unit (Table 4). Compared with the South Unit, the North Unit had a higher proportion of high seral grass, forb, and sedge species that would be able to revegetate the area to a more desirable community if Canada thistle were controlled. However, a longterm management program would still have to be implemented after Canada thistle was controlled because a high percentage of the seedbank consisted of undesirable species.

Soil seedbank density and richness were not affected by the prescribed burn that was implemented the fall before sampling. Data were homogenous by location and were combined for all 8 categories (Table 5). Similar among treatments, the average seedling density was 2148 plants $\cdot \mathrm{m}^{-2}$ in the burned areas and 2983 plants $\cdot \mathrm{m}^{-2}$ in the nonburned treatments. Of the 
treatments, Canada thistle was $15 \%$ of the total seedlings identified in the burned areas and $29 \%$ in the nonburned areas. Although not significantly affected by the prescribed burn, the number of Canada thistle seedlings in the burned plot areas may have been reduced because seeds remained in flower heads in the fall when the area was burned.

The percentage of low seral forbs tended to be higher in burned treatments with an average of $45 \%$ of the total seedlings identified compared with the nonburned treatments with $28 \%$ of the total (Table 5). Prescribed burns may improve the environment for establishment of native forb species (DiTomaso et al. 1999). In this study, litter was reduced from $16 \%$ to $3 \%$ the season following a fall burn (Table 3 ) and may have improved the germination and establishment of endemic native forb species that require a high amount of light and warm soil temperatures.

The number of Canada thistle seedlings from the seedbank of the South and North Units of TRNP was not affected by fire. However, low seral and invasive species including Canada thistle and Kentucky bluegrass accounted for over $80 \%$ of the total species identified across the burned and nonburned areas (Table 5). Therefore, a long-term management program would have to be implemented to reduce undesirable species and/or revegetate these sites following control of Canada thistle.

\section{MANAGEMENT IMPLICATIONS}

Before this study, land managers at TRNP observed an increase in Canada thistle density following prescribed burns conducted to manage and restore grassland ecosystems. The results of this study suggest that fall prescribed burns did not cause a longterm increase in Canada thistle density, rather Canada thistle emerged earlier in the burned areas compared with the nonburned areas. The effect was short-lived and Canada thistle densities were similar regardless of burn treatment the second growing season after the burn.

A combination of control practices has often been suggested to reduce Canada thistle infestations because the weed may resist a single management practice (Evans 1984; Duncan et al. 2004). However, in this study no differences were found in Canada thistle control when herbicides were used alone or combined with a prescribed burn. In addition, soil seedbank and diversity were not affected by the prescribed burn.

Land managers at TRNP continue to implement prescribed burns followed by herbicide application as part of their management plan to control Canada thistle and other undesirable species found within the park. Managers first identify the species composition within an area to determine their management objectives. Areas with low densities of undesirable species generally receive only fall-maintenance burns with no followup herbicide treatment. However, areas with a high density of invasive weeds, such as Canada thistle, typically receive both a prescribed burn and herbicide treatment. Once undesirable plants are controlled, land managers should consider reseeding areas to more desirable species. Reseeding may be especially important in restoring desired vegetation considering that the majority of the soil seedbank sampled in Canada thistleinfested areas of TRNP consisted of undesirable species.

\section{ACKNOWLEDGMENT}

Authors wish to thank Katheryn Christianson for technical assistance with field work and data analysis.

\section{LITERATURE CITED}

Balasko, J. A., G. W. Evers, and R. W. Duell. 1995. Bluegrasses, ryegrasses, and bentgrasses. In: R. F. Barnes, D. A. Miller, C. J. Nelson [eds.]. Forages: An introduction to grassland agriculture. Vol. 1. Ames, IA: Iowa State Univ. Press. p 357-372.

Beck, K. G., and J. R. Sebastian. 2000. Combining mowing and fall-applied herbicides to control Canada thistle (Cirsium arvense). Weed Technology 14:351-356.

Carmer, S. G., W. E. Nyquist, and W. M. Walker. 1989. Least significant differences for combined analyses of experiments with two- or three-factor treatment designs. Agronomy Journal 81:665-672.

Carrithers, V. F., R. N. Klein, S. Z. Knezevic, R. A. Masters, T. C. Geselius, J. D. Green, ANd P. L. Burch. 2001. Chemical control of Canada thistle on rangeland and pastures [abstract]. In: R. G. Hartzler [ed.]. Proceedings North Central Weed Science Society; 10-13 December 2001; Milwaukee, WI. 56: Abstract No. 164.

DaUbenmiRe, R. F. 1959. A canopy-cover method of vegetational analysis. Northwest Science 33:43-66.

Ditomaso, J. M., G. B. Kyser, AND M. S. Hastings. 1999. Prescribed burning for control of yellow starthistle (Centaurea solstitialis) and enhanced native plant diversity. Weed Science 47:233-242.

Donald, W. W. 1990. Management and control of Canada thistle (Cirsium arvense). Reviews of Weed Science 5:193-250.

DonalD, W. W. 1993. Retreatment with fall-applied herbicides for Canada thistle (Cirsium arvense) control. Weed Science 41:434-440.

Duncan, C. A., J. J. Jachetta, M. L. Brown, V. F. Carrithers, J. K. Clark, J. M. DiTomaso, R. G. Lym, K. C. McDaniel, M. J. Renz, and P. M. Rice. 2004. Assessing the economic, environmental, and societal losses from invasive plants on rangeland and wildlands. Weed Technology 18: 1411-1416.

Eggers, S. D., And D. M. Reed 1997. Wetland plants and communities of Minnesota and Wisconsin. U.S. Army Corps Eng., St. Paul District. Northern Prairie Wildlife Research Center Home Page. Available at http://www.npwrc.usgs.gov/ resource/1998/mnplant/mnplant.htm. Ver. 03SEP98. Accessed 13 October 2003.

Evans, J. E. 1984. Canada thistle (Cirsium arvense): A literature review of management practices. Natural Areas Journal 4:11-21.

Great Plains Flora Association. 1986. Flora of the Great Plains. Lawrence, KS: University Press of Kansas. $1392 \mathrm{pp}$.

Hansen, R. 2001. Integrated management of Canada thistle: Current status and future prospects [unpublished report]. USDA-APHIS-PPQ. Bozeman, MT: Bozeman Biological Control Lab. $22 \mathrm{p}$.

HulbeRT, L. C. 1988. Causes of fire effects in tallgrass prairie. Ecology 69:46-58. JACOBS, J. S., AND R. L. ShelEy. 2003. Prescribed fire effects on dalmation toadflax. Journal of Range Management. 56:193-197.

Kirby, D. R., R. G. Lym, J. J. Sterling, and C. Hull Sieg. 2003. Observation: leafy spurge control in western prairie fringed orchid habitat. Journal of Range Management 56:466-473.

Kruger, F. J. 1983. Plant community diversity and dynamics in relation to fire. Ecological Studies 43:446-472.

Kyser, G. B. AND J. M. DiTomaso. 2002. Instability in a grassland community after the control of yellow starthistle (Centaurea solstitialis) with prescribed burning. Weed Science 50:648-657.

Lauridson, T. C., R. G. Wilson, and L. C. Haderlie. 1983. Effect of moisture stress on Canada thistle (Cirsium arvense) control. Weed Science 31:674-680.

LARSON, G. E. 1993. Aquatic and wetland vascular plants of the northern Great Plains. Fort Collins, CO: US Department of Agriculture, Forest Service, Rocky 
Mountain Forest and Range Experiment Station. Gen. Tech. Rep. RM-238. Jamestown, ND: Northern Prairie Wildlife Research Center Home Page. Available at: http://www.npwrc.usgs.gov/resources/1999/vascplnt/ vascplnt.htm. Ver. 02FEB99. Accessed 21 October 2003.

Lee, A. T., M. W. Marshall, J. D. Green, and W. W. Witt. 2001. Canada thistle control with spring-applied clopyralid and triclopyr [abstract]. In: R. G. Hartzler [ed.]. Proceedings North Central Weed Science Society; 10-13 December 2001; Milwaukee, WI. 56: Abstract No. 117. (CD).

LYM, R. G. 2003. Evaluation of various herbicide mixtures applied in May or September for Canada thistle control. In: J. Campbell and T. Rauch [eds.]. Research Progress Report Western Society Weed Science. $p$ 4-5.

MilleR, B. R., AND R. G. LYM. 1998. Using the rosette technique for Canada thistle (Cirsium arvense) control in row crops. Weed Technology 12:699-706.

Moore, R. J. 1975. The biology of Canadian weeds 13: Cirsium arvense (L.) Scop. Canadian Journal of Plant Science 55:1033-1048.

[NPS] National Park Service. 1997. Fire management program: environmental assessment/assessment of effect. Medora, ND: Theodore Roosevelt National Park. p 58.

Perez, C. J., S. S. Waller, L. E. Moser, J. L. Stubbendieck, and A. A. Steuter. 1998. Seedbank characteristics of a Nebraska sandhills prairie. Journal of Range Management 51:55-62.

Pollack, O., AND T. Kan. 1998. The use of prescribed fire to control invasive exotic weeds at Jepson Prairie Preserve. In: C. W. Witham, E. T. Bauder, D. Belk W. R. Ferren, Jr., and R. Ornduff, [eds.]. Ecology, conservation, and management of vernal pool ecosystems (1996). Sacramento, CA: Proceedings California Native Plant Society. p 241-249.

Reever Morghan, K. J., T. R. Seastedt, and P. J. Sinton. 2000. Frequent fire slows invasion of ungrazed tallgrass prairie by Canada thistle (Colorado). Ecological Restoration 18:194-195.

RowE, J. S. 1983. Concepts of fire effects on plant individuals and species. In: R. W. Wein and D. A. MacLean, [eds.]. The role of fire in northern circumpolar ecosystems. SCOPE 18. New York, NY: John Wiley \& Sons. p 135-154.
Schimel, D. S., T. G. F. Kittel, A. K. Knapp, T. R. Seastedt, W. J. Parton, and V. B. BRown. 1991. Physiological interactions along resource gradients in a tallgrass prairie. Ecology 72:672-684.

Sharrow, S. H., and H. A. Wright. 1977. Effects of fire, ash, and litter on soil nitrate, temperature, moisture and tobosagrass production in the rolling plains. Journal of Range Management 30:266-270.

Sheley, R. L., AND B. R. Roche, JR. 1982. Rehabilitation of spotted knapweed infested rangeland in northeastern Washington. In: L. Anderson [ed.]. Proceedings Western Society Weed Science 35:31; 9-11 March 1982; Denver, C0.

Sheley, R. L., J. S. Jacobs, and M. L. Carpinelli. 1998. Distribution, biology, and management of diffuse (Centaurea diffusa) and spotted knapweed (Centaurea maculosa). Weed Technology 12:353-362.

Sмiтн, K. A. 1985. Canada thistle response to prescribed burning (North Dakota). Restoration Management Notes 3: Note 94.

Templeton, A. R., AND D. A. Levin. 1979. Evolutionary consequences of seed pools. American Naturalist 114:232-249.

Ter Heerdt, G. N. J., G. L. VerweiJ, R. M. Bekker, and J. P. Bakker. 1996. An improved method for seed bank analysis: seedling emergence after removing the soil by sieving. Functional Ecology 10:144-151.

The Northern Great Plains Floristic Quality Assessment Panel. 2001. Coefficients of conservation for the vascular flora of the Dakotas and adjacent grasslands. US Geological Survey, Biological Resources Division, Information and Technology Report USGS/BRD/ITR-2001-0001. Springfield, VA: National Technical Information. $p 32$.

Wilson, R. G., and S. D. Kachman. 1999. Effect of perennial grasses on Canada thistle (Cirsium arvense) control. Weed Technology 13:83-87.

Young, R. P. 1986. Fire ecology and management in plant communities of Malheur National Wildlife Refuge [thesis]. Corvallis, OR: Oregon State University. $169 \mathrm{p}$.

ZouHAR, K. 2001. Cirsium arvense: Fire case studies. Malheur National Wildlife Refuge. Available at: http://www.fs.fed.us/database/feis/plants/forb/cirarv/ index.html. Accessed 14 December 2003. 